\title{
Analisis Tingkat Kesehatan Bank Menggunakan Metode RGEC (Risk Profile, Good Corporate Governance, Earnings, dan Capital) Pada Bank Umum Periode 2018-2020
}

Muhamad Bayu Nur Rohman

Prodi Manajemen Bisnis, Fakultas Ekonomi dan Bisnis, Universitas Islam Bandung, Indonesia.

muhamadbayu751@gmail.com

\begin{abstract}
This study aims to determine the health level of BUMN Commercial Banks from the aspects of Risk Profile, Good Corporate Governance, Earnings, Capital and RGEC as a whole. The author uses 4 sample companies with a time period of 2018-2020. This research uses descriptive quantitative research methods. The data analysis technique used is descriptive analysis with reference to POJK No. 4/POJK.03/2016. The results showed that in terms of the Risk Profile, the NPL ratio of BUMN Commercial Banks for the 2018-2020 period was categorized as "Healthy". From the GCG aspect, it shows that the 2018-2020 period of state-owned commercial banks is categorized as "Healthy". In terms of earnings, it shows that in 2018-2020 the ROA of BUMN Commercial Banks was categorized as "Very Healthy", and in 2020 it was categorized as "Fairly Healthy". Furthermore, the 2018-2020 NIM is categorized as "Very Healthy". In terms of capital, it shows that in the 2018-2020 period, state-owned commercial banks were categorized as "Very Healthy". In terms of RGEC as a whole, in 2018-2019 BUMN Commercial Banks were categorized as "Very Healthy", while in 2020 they were categorized as "Healthy".
\end{abstract}

Keywords - Bank Health, Risk Profile, GCG, Earnings, Capital

Abstrak. Penelitian ini bertujuan untuk mengetahui tingkat kesehatan Bank Umum BUMN dari aspek Risk Profile, Good Corporate Governance, Earnings, Capital dan RGEC secara keseluruhan. Penulis menggunakan 4 sampel perusahaan dengan periode waktu 2018-2020. Penelitian ini menggunakan metode penelitian deskriptif kuantitatif. Teknik analisis data yang digunakan adalah analisis deskriptif dengan acuan POJK No. 4/POJK.03/2016. Hasil penelitian menunjukkan dari segi Risk Profile bahwa rasio NPL Bank Umum BUMN periode 2018-2020 dikategorikan "Sehat. Dari aspek GCG menunjukkan bahwa periode 2018-2020 Bank Umum BUMN dikategorikan "Sehat". Dari segi earnings menunjukkan bahwa pada tahun 2018-2020 ROA Bank Umum BUMN dikategorikan "Sangat Sehat", dan di tahun 2020 dikategorikan "Cukup Sehat". Selanjutnya NIM pada tahun 2018-2020 dikategorikan "Sangat Sehat". Dari segi capital menunjukkan bahwa pada periode 2018-2020 Bank Umum BUMN dikategorikan "Sangat Sehat". Dari segi RGEC secara keseluruhan, pada tahun 2018-2019 Bank Umum BUMN dikategorikan "Sangat Sehat", sedangkan di tahun 2020 dikategorikan "Sehat".

Kata Kunci- Kesehatan Bank, Risk Profile, GCG, Earnings, Capital 


\section{A. Pendahuluan}

Dalam rangka mewujudkan pertumbuhan ekonomi, perbankan merupakan salah satu sektor yang paling berperan aktif dalam pembangunan ekonomi suatu negara. Menurut Pramana dan Artini (2016), perbankan adalah lembaga yang berperan sebagai intermediasi atau perantara antara pihak yang memiliki dana yang berlebih (defisit spending unit) dengan pihak lain yang sedang mengalami kekurangan dana (defisit spending unit) yang mana hal tersebut secara tidak langsung dapat membantu perputaran uang yang beredar di masyarakat. Maka dari itu, dengan tidak adanya bank sebagai lembaga intermediasi, maka kedua belah pihak tersebut akan kesulitan dalam melaksanakan kegiatan ekonominya.

Dalam menjalankan kegiatan operasionalnya agar tetap berjalan dengan lancar, unsur kepercayaan masyarakat merupakan salah satu aspek yang amat penting bagi dunia perbankan. Jika masyarakat telah memiliki kepercayaan terhadap salah satu bank, maka ia akan berminat untuk memakai jasa dari bank tersebut. Salah satu hal yang dapat membuat masyarakat memiliki kepercayaan terhadap suatu bank adalah tingkat kesehatan dari bank tersebut. Bila suatu bank dinyatakan sedang berada pada kondisi yang sehat, maka memungkinkan masyarakat dapat tertarik untuk menyimpan dana yang dimilikinya untuk dikelola oleh bank tersebut. Dan begitupun sebaliknya, bila suatu bank dinyatakan sedang berada pada kondisi yang tidak stabil atau bahkan tidak sehat, maka kemungkinan besar minat serta keyakinan masyarakat pada bank tersebut akan menurun.

Kesehatan bank yaitu kemampuan bank dalam melaksanakan kegiatan operasionalnya secara normal serta seluruh kewajibannya dapat dipenuhi dengan baik dan dilakukan sesuai dengan peraturan yang telah berlaku (Budisantoso \& Nuritomo, 2014). Sedangkan tingkat kesehatan bank menurut Peraturan Otoritas Jasa Keuangan No. 4/POJK.03/2016 adalah hasil penilaian kondisi Bank yang dilakukan terhadap risiko dan kinserja bank. Tujuan dilakukannnya penilaian tingkat kesehatan bank adalah agar para stakeholder perbankan mengetahui kondisi suatu bank tersebut sedang dalam kondisi Sangat Sehat, Sehat, Cukup Sehat, Kurang Sehat, atau Tidak Sehat.

Otoritas Jasa Keuangan selaku lembaga yang berperan melakukan pengawasan terhadap kinerja bank di Indonesia telah membuat sebuah peraturan mengenai analisis tingkat kesehatan bank. Berdasarkan Peraturan Otoritas Jasa Keuangan Nomor 4/POJK.03/2016 tentang penilaian kesehatan bank umum, bahwa setiap bank wajib melakukan penilaian tingkat kesehatan bank dengan menggunakan pendekatan risiko (Risk-based Bank Rating) dengan cakupan penilaian terhadap faktor-faktor profil risiko (risk profile), Good Corporate Governance (GCG), Rentabilitas (Earnings), dan permodalan (Capital). Dan kemudian saat ini analisis tingkat kesehatan bank dengan menggunakan metode tersebut lebih dikenal dengan metode RGEC.

Berdasarkan fenomena yang telah dipaparkan di atas, maka dari itu peneliti memiliki ketertarikan untuk membuat sebuah penilitian yang berjudul "ANALISIS TINGKAT KESEHATAN BANK MENGGUNAKAN METODE RGEC (RISK PROFILE, GOOD CORPORATE GOVERNANANCE, DAN CAPITAL) PADA BANK UMUM BUMN PERIODE 2018-2020."

Berdasarkan latar belakang masalah di atas, maka tujuan dari penulisan penelitian ini adalah sebagai berikut:

1. Mengetahui tingkat kesehatan dari bank bila ditinjau dari segi aspek Risk Profile pada bank umum BUMN periode 2018-2020.

2. Mengetahui tingkat kesehatan dari bank bila ditinjau dari segi aspek Good Corporate Governance pada bank umum BUMN periode 2018-2020.

3. Mengetahui tingkat kesehatan dari bank bila ditinjau dari segi aspek Earnings pada bank umum BUMN periode 2018-2020.

4. Mengetahui tingkat kesehatan dari bank bila ditinjau dari segi aspek Capital pada bank umum BUMN periode 2018-2020.

5. Mengetahui tingkat kesehatan dari bank bila ditinjau pada segi aspek $R G E C$ pada bank umum BUMN periode 2018-2020.

\section{B. Metodologi Penelitian}

Metode penelitian yang akan digunakan dalam penelitian ini adalah penelitian deskriptif dengan pendekatan kuantitatif. Menurut Nazir (2013), pengertian deskriptif adalah suatu metode dalam meneliti status sekelompok manusia, suatu objek, suatu set kondisi, suatu sistem pemikiran, ataupun suatu kelas peristiwa pada masa sekarang. Dalam penelitian ini menggunakan data sekunder dengan teknik pengumpulan data studi kepustakaan dan dokumentasi. Dan teknik analisis data yang digunakan dalam penelitian ini adalah teknik analisis deskriptif dengan acuan 
Peraturan Otoritas Jasa Keuangan Nomor 4/POJK.03/2016 dan SEOJK No. 14/SEOJK.03/2017 tentang Penilaian Tingkat Kesehatan Bank Umum.

\section{Bank}

Menurut Hasibuan (2015), bank adalah sebuah lembaga pengumpul dana dan penyalur kredit yang berarti dalam operasionalnya mengumpulkan dana dari Surplus Spending Unit (SSU) dan menyalurkan kredit kepada Defisit Spending Unit (DSU). Sedangkan menurut UU No 10 tahun 1998, pengertian bank adalah badan usaha yang menghimpun dana darimasyarakat dalam bentuk simpanan dan menyalurkannya kepadamasyarakat dalam bentuk kredit dan atau bentukbentuk lainnya dalam rangka meningkatkan taraf hidup rakyat banyak.

\section{Kesehatan Bank}

Kesehatan bank yaitu kemampuan bank dalam melaksanakan kegiatan operasionalnya secara normal serta seluruh kewajibannya dapat dipenuhi dengan baik dan dilakukan sesuai dengan peraturan yang telah berlaku (Budisantoso \& Nuritomo, 2014).

\section{Analisis Tingkat Kesehatan Bank}

Berdasarkan Peraturan Otoritas Jasa Keuangan nomor 4/POJK.03/2016 tentang penilaian kesehatan bank umum, Tingkat Kesehatan Bank adalah hasil penilaian kondisi Bank yang dilakukan terhadap risiko dan kinerja Bank. Dalam peraturan tersebut dijelaskan bahwa setiap bank wajib melakukan penilaian tingkat kesehatan bank dengan menggunakan pendekatan risiko (Risk-based Bank Rating) dengan cakupan penilaian terhadap faktor-faktor profil risiko (risk profile), Good Corporate Governance (GCG), Rentabilitas (Earnings), dan permodalan (Capital). Dan penilaian tingkat kesehatan bank dengan menggunakan faktor-faktor tersebut pada saat ini lebih dikenal dengan metode RGEC.

\section{Hasil Penelitian dan Pembahasan}

\section{Risk Profile}

Tabel 1. Rasio NPL Bank Umum BUMN 2018-2020

\begin{tabular}{|c|c|c|c|c|}
\hline Tahun & Nama Bank & NPL & $\begin{array}{l}\text { Peringkat } \\
\text { Komposit }\end{array}$ & Kategori \\
\hline \multirow{5}{*}{2018} & BRI & $1,17 \%$ & 1 & Sangat Sehat \\
\hline & BNI & $1,96 \%$ & 1 & Sangat Sehat \\
\hline & Mandiri & $2,79 \%$ & 2 & Sehat \\
\hline & BTN & $2,81 \%$ & 2 & Sehat \\
\hline & Rata-Rata & $2,18 \%$ & 2 & Sehat \\
\hline \multirow{5}{*}{2019} & BRI & $1,31 \%$ & 1 & Sangat Sehat \\
\hline & BNI & $2,33 \%$ & 2 & Sehat \\
\hline & Mandiri & $2,38 \%$ & 2 & Sehat \\
\hline & BTN & $5,53 \%$ & 3 & Cukup Sehat \\
\hline & Rata-Rata & $2,89 \%$ & 2 & Sehat \\
\hline \multirow{2}{*}{2020} & BRI & $1,28 \%$ & 1 & Sangat Sehat \\
\hline & BNI & $4,20 \%$ & 2 & Sehat \\
\hline
\end{tabular}




\begin{tabular}{|l|l|r|c|c|}
\hline \multirow{2}{*}{ Mandiri } & $3,25 \%$ & 2 & Sehat \\
\cline { 2 - 5 } & BTN & $4,37 \%$ & 2 & Sehat \\
\cline { 2 - 5 } & Rata-Rata & $3,275 \%$ & 2 & Sehat \\
\hline
\end{tabular}

Sumber: Berdasarkan tabel di atas, maka dapat dilihat bahwa mayoritas nilai NPL pada Bank Umum BUMN periode 2018-2020 memiliki tren yang fluktuatif. Tercatat hanya Bank BNI saja yang pada periode tersebut memiliki tren yang negatif, yakni selalu terjadi peningkatan nilai NPL di setiap tahunnya. Peningkatan nilai NPL yang paling tinggi yang terjadi pada Bank BNI yaitu pada tahun 2020, yang mana mengalami peningkatan NPL sebesar 1,87\%, dari yang semulanya $2,33 \%$ menjadi $4,20 \%$. Hal itu bisa terjadi dikarenakan melemahnya kualitas kredit dari bank BNI pada tahun tersebut. Pada tahun 2020, kredit bermasalah dari Bank BNI melonjak tinggi hingga mencapai angka 24.629.844 (dalam jutaan rupiah), dari yang sebelumnya yakni pada tahun 2019 sebesar 12.961.816 (dalam jutaan rupiah).

Namun, secara keseluruhan nilai rata-rata NPL pada Bank Umum BUMN memiliki tren yang negatif. Hal tersebut dikarenakan nilai rata-rata NPL pada Bank Umum BUMN setiap tahunnya selalu terjadi peningkatan. Namun peningkatan rata-rata nilai NPL yang terjadi pada Bank BUMN tidak berpengaruh terhap tingkat kesehatan banknya. Hal ini dikarenakan pada periode 2018-2020 tingkat kesehatan Bank Umum BUMN dari segi NPL memiliki peringkat yang sama, yaitu peringkat 2 atau yang dikategorikan sehat.

\section{Good Corporate Governance}

Tabel 2. Peringkat GCG Bank Umum BUMN 2018-2020data diolah, 2021

\begin{tabular}{|c|c|c|c|c|}
\hline Tahun & Nama Bank & GCG & $\begin{array}{l}\text { Peringkat } \\
\text { Komposit }\end{array}$ & Kategori \\
\hline \multirow{5}{*}{2018} & BRI & 2 & 2 & Baik \\
\hline & $\mathrm{BNI}$ & 2 & 2 & Baik \\
\hline & Mandiri & 1 & 1 & Sangat Baik \\
\hline & BTN & 2 & 2 & Baik \\
\hline & Rata-Rata & 1,75 & 2 & Baik \\
\hline \multirow{5}{*}{2019} & BRI & 2 & 2 & Baik \\
\hline & $\mathrm{BNI}$ & 2 & 2 & Baik \\
\hline & Mandiri & 1 & 1 & Sangat Baik \\
\hline & BTN & 2 & 2 & Baik \\
\hline & Rata-Rata & 1,75 & 2 & Baik \\
\hline \multirow{5}{*}{2020} & BRI & 2 & 2 & Baik \\
\hline & BNI & 2 & 2 & Baik \\
\hline & Mandiri & 1 & 1 & Sangat Baik \\
\hline & BTN & 2 & 2 & Baik \\
\hline & Rata-Rata & 1,75 & 2 & Baik \\
\hline
\end{tabular}

Sumber: data diolah, 2021

Berdasarkan tabel di atas, dapat dilihat bahwa pertumbuhan peringkat komposit GCG pada tiap Bank Umum BUMN periode 2018-2020 memiliki tren atau kecenderungan yang datar/flat. Tiga dari empat Bank Umum BUMN, yaitu Bank BRI, Bank Mandiri, dan Bank BTN kompak serta konsisten meraih peringkat komposit 2 secara tiga tahun berturut-turut pada periode tersebut yang berarti tingkat kesehatan bank dalam aspek GCG dari bank-bank tersebut dikategorikan sehat. Sedangkan Bank Mandiri menjadi satu-satunya bank yang mampu memperoleh peringkat komposit GCG dengan peringakat 1. Dan lebih hebatnya lagi Bank Mandiri mampu mempertahankan peringkat tersebut secara tiga tahun berturut-turut. Artinya tingkat Kesehatan Bank Mandiri jika ditinjau dari aspek GCG dikategorikan sangat sehat.

Sedangkan secara keseluruhan, nilai rata-rata GCG pada Bank Umum BUMN periode 2018-2020 juga memiliki kecenderungan yang datar (flat). Selama tiga tahun berturut-turut peringkat komposit GCG dari Bank Umum BUMN memperoleh peringkat 2 yang berarti tingkat 
kesehatan banknya dari aspek GCG dikategorikan sehat. Dengan memperoleh peringkat komposit 2 atau yang dikategorikan sehat, maka hal tersebut menunjukkan bahwa secara keseluruhan manajemen dari Bank Umum BUMN telah menerapkan prinsip-prinsip tata kelola atau Good Corporate Governance (GCG) dengan baik. Dan jika terdapat suatu kelemahan pun, maka kelemahan tersebut tidak terjadi secara signifikan dan dapat diselesaikan dengan tindakan normal oleh manajamen bank.

\section{Earnings}

Tabel 3. Rasio ROA Bank Umum BUMN 2018-2020

\begin{tabular}{|c|c|c|c|c|}
\hline \multirow{3}{*}{ Tahun } & Nama Bank & ROA & $\begin{array}{c}\text { Peringkat } \\
\text { Komposit }\end{array}$ & Kategori \\
\hline \multirow{4}{*}{2018} & BRI & $3,30 \%$ & 1 & Sangat Sehat \\
\cline { 2 - 5 } & BNI & $2,52 \%$ & 1 & Sangat Sehat \\
\cline { 2 - 5 } & Mandiri & $3,02 \%$ & 1 & Sangat Sehat \\
\cline { 2 - 5 } & BTN & $1,18 \%$ & 3 & Cukup Sehat \\
\cline { 2 - 5 } & Rata-Rata & $2,505 \%$ & 1 & Sangat Sehat \\
\cline { 2 - 5 } & BRI & $3,20 \%$ & 1 & Sangat Sehat \\
\cline { 2 - 5 } & BNI & $2,34 \%$ & 1 & Sangat Sehat \\
\cline { 2 - 5 } & Mandiri & $2,87 \%$ & 1 & Sangat Sehat \\
\cline { 2 - 5 } & BTN & $0,13 \%$ & 5 & Tidak Sehat \\
\hline \multirow{3}{*}{2020} & Rata-Rata & $2,135 \%$ & 1 & Sangat Sehat \\
\cline { 2 - 5 } & BRI & $1,84 \%$ & 1 & Sangat Sehat \\
\cline { 2 - 5 } & BNI & $0,53 \%$ & 4 & Kurang Sehat \\
\cline { 2 - 5 } & Mandiri & $1,57 \%$ & 1 & Sangat Sehat \\
\cline { 2 - 5 } & BTN & $0,63 \%$ & 4 & Cukup Sehat \\
\hline
\end{tabular}

Sumber: data diolah, 2021

Berdasarkan tabel di atas, pertumbuhan nilai ROA Bank Umum BUMN pada periode 2018-2020 cenderung menunjukkan tren yang negatif. Hal ini dikarenakan tiga dari empat Bank Umum BUMN yaitu Bank BRI, BNI, dan Mandiri selalu mengalami penurunan ROA di setiap tahunnya. Penurunan ROA ini disebabkan oleh meningkatnya Cadangan Kerugian Penurunan Nilai (CKPN) pada Bank Umum BUMN khususnya pada Bank BRI, BNI, dan Mandiri. Peningkatan CKPN ini terjadi dikarenakan hal tersebut adalah salah satu upaya yang dilakukan oleh bank untuk mengantisipasi naiknya risiko kredit.

Secara keseluruhan, meskipun rata-rata nilai ROA pada Bank Umum BUMN memiliki tren yang negatif yaitu selalu terjadi penurunan dari tahun ke tahun, tetapi Peringkat Komposit ROA pada tahun 2019 masih sama dengan tahun sebelumnya, yaitu mendapatkan Peringkat Komposit 1 yang berarti masih dikategorikan sangat sehat. Tetapi, tren negatif rata-rata nilai ROA tersebut sangat terlihat pada tahun 2020 yang mana terjadinya penurunan Peringkat Komposit dari tahun sebelumnya. Jika pada tahun 2019 rata-rata nilai ROA pada Bank Umum BUMN memperoleh Peringkat Komposit 1, maka pada tahun 2020 Peringkat Komposit tersebut menurun menjadi Peringkat Komposit 3 yang berarti dikategorikan cukup sehat.

Tabel 4. Rasio NIM Bank Umum BUMN 2018-2020

\begin{tabular}{|c|l|r|r|c|}
\hline \multirow{2}{*}{ Tahun } & \multicolumn{1}{|c|}{ Nama Bank } & NIM & $\begin{array}{c}\text { Peringkat } \\
\text { Komposit }\end{array}$ & Kategori \\
\hline \multirow{3}{*}{2018} & BRI & $7,08 \%$ & 1 & Sangat Sehat \\
\cline { 2 - 5 } & BNI & $5,11 \%$ & 1 & Sangat Sehat \\
\cline { 2 - 5 } & Mandiri & $5,15 \%$ & 1 & Sangat Sehat \\
\cline { 2 - 5 } & BTN & $3,99 \%$ & 1 & Sangat Sehat \\
\cline { 2 - 5 } & Rata-Rata & $5,33 \%$ & 1 & Sangat Sehat \\
\hline \multirow{2}{*}{2019} & BRI & $6,88 \%$ & 1 & Sangat Sehat \\
\cline { 2 - 5 } & BNI & $4,93 \%$ & 1 & Sangat Sehat \\
\hline
\end{tabular}




\begin{tabular}{|c|l|l|l|l|}
\hline \multirow{7}{*}{} & Mandiri & $5,10 \%$ & 1 & Sangat Sehat \\
\cline { 2 - 5 } & BTN & $3,22 \%$ & 1 & Sangat Sehat \\
\cline { 2 - 5 } & Rata-Rata & $5,03 \%$ & 1 & Sangat Sehat \\
\hline \multirow{5}{*}{2020} & BRI & $5,68 \%$ & 1 & Sangat Sehat \\
\cline { 2 - 5 } & BNI & $4,72 \%$ & 1 & Sangat Sehat \\
\cline { 2 - 5 } & Mandiri & $4,37 \%$ & 1 & Sangat Sehat \\
\cline { 2 - 5 } & BTN & $2,76 \%$ & 1 & Sehat \\
\cline { 2 - 5 } & Rata-Rata & $4,38 \%$ & 1 & Sangat Sehat \\
\hline
\end{tabular}

Sumber: data diolah, 2021

Berdasarkan tabel di atas, maka dapat diketahui bahwa pertumbuhan nilai NIM pada Bank Umum BUMN memiliki tren yang negatif. Hal ini dapat dibuktikan dengan melihat pertumbuhan nilai NIM dari seluruh Bank Umum BUMN selalu mengalami penurunan di setiap tahunnya. Namun, penurunan nilai NIM tersebut tidak terjadi secara signifikan. Dapat terlihat bahwa penurunan nilai NIM pada Bank Umum BUMN periode 2018-2020 tidak ada yang melebihi dari $1 \%$.

Secara keseluruhan, nilai rata-rata NIM Bank Umum BUMN pada periode 2018-2020 memiliki tren yang negatif. Dari tahun ke tahun, nilai rata-rata NIM pada Bank Umum BUMN selalu terjadi penurunan. Pada tahun 2019, terjadi penurunan nilai rata-rata NIM sebesar 0,30\%. Dan kemudian di tahun berikutnya kembali terjadi penurunan sebesar $0,65 \%$.

Namun di sisi lain, meskipun rata-rata nilai NIM pada Bank BUMN pada periode tersebut memiki tren yang negatif, hal tersebut tidak berdampak sama sekali terhadap tingkat kesehatan bank dari segi NIM. Hal ini terbukti dengan nilai rata-rata tingkat kesehatan Bank Umum BUMN dari segi NIM selalu mendapatkan peringkat 1 , yang berati dikategorikan sangat sehat. Artinya, manajemen dari bank umum BUMN memiliki kemampuan yang baik dalam mengelola aset produktifnya sehingga bisa menghasilkan pendapatan bunga bersih yang baik pula.

\section{Capital}

Tabel 5. Rasio CAR Bank Umum BUMN 2018-2020

\begin{tabular}{|c|l|c|c|c|}
\hline \multirow{2}{*}{ Tahun } & \multicolumn{1}{|c|}{ Nama Bank } & CAR & $\begin{array}{c}\text { Peringkat } \\
\text { Komposit }\end{array}$ & Kategori \\
\hline \multirow{5}{*}{2018} & BRI & $21,21 \%$ & 1 & Sangat Sehat \\
\cline { 2 - 5 } & BNI & $18,50 \%$ & 1 & Sangat Sehat \\
\cline { 2 - 5 } & Mandiri & $20,96 \%$ & 1 & Sangat Sehat \\
\cline { 2 - 5 } & BTN & $18,20 \%$ & 1 & Sangat Sehat \\
\cline { 2 - 5 } & Rata-Rata & $19,72 \%$ & 1 & Sangat Sehat \\
\hline \multirow{5}{*}{2019} & BRI & $22,55 \%$ & 1 & Sangat Sehat \\
\cline { 2 - 5 } & BNI & $19,73 \%$ & 1 & Sangat Sehat \\
\cline { 2 - 5 } & Mandiri & $21,39 \%$ & 1 & Sangat Sehat \\
\cline { 2 - 5 } & BTN & $17,32 \%$ & 1 & Sangat Sehat \\
\cline { 2 - 5 } & Rata-Rata & $20,25 \%$ & 1 & Sangat Sehat \\
\hline \multirow{5}{*}{2020} & BRI & $20,61 \%$ & 1 & Sangat Sehat \\
\cline { 2 - 5 } & BNI & $16,78 \%$ & 1 & Sangat Sehat \\
\cline { 2 - 5 } & Mandiri & $19,90 \%$ & 1 & Sangat Sehat \\
\cline { 2 - 5 } & BTN & $19,34 \%$ & 1 & Sangat Sehat \\
\cline { 2 - 5 } & Rata-Rata & $19,16 \%$ & 1 & Sangat Sehat \\
\hline
\end{tabular}

Sumber: data diolah, 2021

Berdasarkan tabel di atas, maka dapat diketahui bahwa pertumbuhan nilai rata-rata rasio CAR pada Bank Umum BUMN periode 2018-2020 memiliki tren atau kecenderungan yang fluktuatif. Tetapi meskipun nilai rasio CAR pada Bank Umum BUMN periode 2018-2020 bersifat fluktuatif, tidak terjadi perubahan nilai rasio CAR yang secara signifikan dari tahun ke tahunnya. Perubahan nilai rasio CAR dari tahun ke tahunnya rata rata tidak lebih dari $1 \%$. Tercatat hanya terdapat satu saja perubahan nilai CAR yang lebih dari $1 \%$, yaitu perubahan nilai CAR pada Bank BNI pada tahun 2020 yang menurun sebesar 2,95\%. 
Secara keseluruhan, meskipun nilai rata-rata CAR pada Bank Umum BUMN periode 2018-2020 memiliki tren yang fluktuatif, tetapi Bank Umum BUMN masih mampu menjaga nilai CAR-nya secara stabil. Hal ini dapat dibuktikan dengan rata-rata peringkat komposit nilai CAR pada Bank Umum BUMN pada periode tersebut mampu memperoleh peringkat komposit 1 secara tiga tahun berturut-turut yang berarti dikategorikan sangat sehat. Dengan memiliki nilai CAR yang besar, maka dapat menunjukkan bahwa bank mampu mengantisipasi berbagai kerugian yang memungkinkan terjadi di kemudian hari.

\section{RGEC Keseluruhan}

Tabel 6. Peringkat Komposit Bank Umum BUMN dari Aspek RGEC

Secara Keseluruhan periode2018-2020

\begin{tabular}{|c|c|c|c|c|c|c|c|c|c|}
\hline \multirow{2}{*}{ Tahun } & \multirow{2}{*}{$\begin{array}{c}\text { Komponen } \\
\text { RGEC }\end{array}$} & \multirow{2}{*}{ Rasio } & \multirow{2}{*}{$\%$ Rasio } & \multicolumn{5}{|c|}{ Peringkat } & \multirow[t]{2}{*}{ Peringkat Komposit } \\
\hline & & & & 1 & 2 & 3 & 4 & 5 & \\
\hline \multirow{6}{*}{2018} & Risk Profile & NPL & $2,18 \%$ & & $\checkmark$ & & & & \multirow{6}{*}{ PK-1 Sangat Sehat } \\
\hline & $G C G$ & GCG & 1,75 & & $\checkmark$ & & & & \\
\hline & \multirow{2}{*}{ Earnings } & ROA & $2,50 \%$ & $\checkmark$ & & & & & \\
\hline & & NIM & $5,33 \%$ & $\checkmark$ & & & & & \\
\hline & Capital & CAR & $19,72 \%$ & $\checkmark$ & & & & & \\
\hline & $\begin{array}{c}\text { Nilai } \\
\text { Komposit }\end{array}$ & & $23 / 25=92$ & 15 & 8 & - & - & - & \\
\hline \multirow{6}{*}{2019} & Risk Profile & NPL & $2,89 \%$ & & $\checkmark$ & & & & \multirow{6}{*}{$\begin{array}{c}\text { PK-1 } \\
\text { Sangat Sehat }\end{array}$} \\
\hline & $G C G$ & GCG & 1,75 & & $\checkmark$ & & & & \\
\hline & \multirow{2}{*}{ Earnings } & ROA & $2,135 \%$ & $\checkmark$ & & & & & \\
\hline & & NIM & $5,03 \%$ & $\checkmark$ & & & & & \\
\hline & Capital & CAR & $20,25 \%$ & $\checkmark$ & & & & & \\
\hline & $\begin{array}{c}\text { Nilai } \\
\text { Komposit } \\
\end{array}$ & & $23 / 25=92$ & 15 & 8 & & & & \\
\hline \multirow{6}{*}{2020} & Risk Profile & NPL & $3,275 \%$ & & $\checkmark$ & & & & \multirow{6}{*}{$\begin{array}{l}\text { PK-2 } \\
\text { Sehat }\end{array}$} \\
\hline & $G C G$ & GCG & 1,75 & & $\checkmark$ & & & & \\
\hline & \multirow{2}{*}{ Earnings } & ROA & $1,14 \%$ & & & $\checkmark$ & & & \\
\hline & & NIM & $4,38 \%$ & $\checkmark$ & & & & & \\
\hline & Capital & CAR & $19,16 \%$ & $\checkmark$ & & & & & \\
\hline & $\begin{array}{l}\text { Nilai } \\
\text { Komposit }\end{array}$ & & $21 / 25=84$ & 10 & 8 & 3 & - & - & \\
\hline
\end{tabular}

Sumber: data diolah, 2021

Secara keseluruhan, tingkat kesehatan Bank Umum BUMN jika ditinjau dari aspek Risk Profile, Good Corporate Governance, Earnings, dan Capital (RGEC) memiliki trend pertumbuhan yang negatif. Pada tahun 2018-2019, tingkat kesehatan bank pada Bank Umum BUMN mampu memperoleh nilai komposit sebesar 92 yang berarti mendapatkan Peringkat Komposit 1 (PK-1). Artinya hal tersebut mencerminkan kondisi bank yang secara umum sangat sehat sehingga dinilai sangat mampu menghadapi pengaruh negatif yang signifikan dari perubahan kondisi bisnis dan faktor eksternal lainnya. Kemudian pada tahun 2020, nilai komposit dari Bank Umum BUMN mengalami penurunan menjadi sebesar 84 dan hal tersebut berdampak pada tingkat kesehatan Bank Umum BUMN yang juga ikut menurun menjadi Peringkat Komposit 2 (PK-2) yang berarti tingkat kesehatan banknya dikategorikan "sehat".

Penurunan tingkat kesehatan bank yang dialami Bank BUMN pada tahun 2020 diakibatkan oleh adanya penurunan kinerja dari Bank BUMN itu sendiri. Penurunan kinerja yang paling 'mencolok' terjadi pada sisi earnings (rentabilitas), yaitu menurunnya peringkat komposit dari Return on Asset (ROA) yang semula berada pada peringkat 1 kemudian menurun dua peringkat menjadi peringkat 3. Hal tersebut mengindikasikan terjadi penurunan perolehan laba yang didapatkan oleh Bank BUMN. Kemudian selain Return on Asset (ROA), kinerja Non Performing Loan (NPL) juga menunjukkan trend atau kecenderungan yang negatif dikarenakan selalu mengalami peningkatan di setiap tahunnya. Selanjutnya kinerja dari Bank BUMN yang memiliki trend atau kecenderungan yang negatif adalah dari segi Net Interest Margin (NIM). Nilai Net Interest Margin (NIM) dari Bank BUMN selalu mengalami penurunan di setiap tahunnya.

\section{Kesimpulan}


Berdasarkan hasil penelitian dan pembahasan yang telah dilakukan, maka dapat ditarik kesimpulan sebagai berikut:

1. Penilaian tingkat kesehatan bank pada Bank Umum BUMN ditinjau dari aspek risk profile dilakukan dengan cara menganalisis risiko kredit dengan menghitung rasio Non Performing Loan (NPL)). Hasil penelitian menunjukkan bahwa pada periode 2018-2020, rasio NPL dari Bank Umum BUMN mampu memperoleh Peringkat Komposit 2 (PK-2) secara tiga tahun berturut-turut yang berarti bank dikategorikan "sehat".

2. Penilaian tingkat kesehatan bank pada Bank Umum BUMN ditinjau dari aspek GCG dilakukan dengan cara melihat laporan assessment GCG yang dilakukan oleh masingmasing bank. Hasil penelitian menunjukkan bahwa pada periode 2018-2020, tingkat kesehatan Bank Umum BUMN dari aspek GCG memperoleh Peringkat Kompositn 2 (PK-2) secara tiga tahun berturut-turut yang berarti bank dikategorikan "sehat".

3. Penilaian tingkat kesehatan bank pada Bank Umum BUMN ditinjau dari aspek earnings dilakukan dengan cara menghitung rasio ROA dan NIM. Rasio ROA Bank Umum BUMN pada periode 2018-2019 memperoleh Peringkat Komposit 1 (PK-1) yang berarti bank dikategorikan "sangat sehat". Namun, pada tahun 2020 peringkat komposit ROA dari Bank Umum BUMN mengalami penurunan menjadi Peringkat Komposit 3 (PK-3) atau yang dikategorikan "cukup sehat". Sedangkan dari segi rasio NIM, pada periode 2018-2020 nilai rata-rata NIM pada Bank Umum BUMN mampu memperoleh Peringkat Komposit 1 yang berarti bank dikategorikan sangat sehat.

4. Penilaian tingkat kesehatan bank pada Bank Umum BUMN dari aspek capital dilakukan dengan cara menghitung rasio Capital Adequacy Ratio (CAR). Hasil penelitian menunjukkan bahwa pada periode 2018-2020 rasio CAR dari Bank Umum BUMN mampu memperoleh Peringkat Komposit 1 (PK-1) secara tiga tahun berturut-turut yang berarti tingkat kesehatan bank dikategorikan "sangat sehat".

5. Hasil penelitian tingkat kesehatan bank dari seluruh komponen RGEC menunjukkan bahwa pada tahun 2018-2019 tingkat kesehatan Bank Umum BUMN mampu memperoleh Peringkat Komposit 1 (PK-1) atau yang dikategorikan "sangat sehat". Dan di tahun 2020 tingkat kesehatan Bank BUMN mengalami penurunan menjadi Peringkat Komposit 2 (PK-2) atau yang dikategorikan "sehat".

\section{Daftar Pustaka}

[1] Budisantoso, T., \& Nuritomo. (2014). Bank dan Lembaga Keuangan Lain Edisi ke-3. Jakarta: Salemba Empat.

[2] Fitriano, Y., \& Sofyan, R. M. (2019). Analisis Tingkat Kesehatan Bank dengan Penerapan Metode RGEC (Risk Profile, Good Corporate Governance, Earnings, dan Capital) Pada PT. Bank Bengkulu . Jurnal Ilmiah Manajemen, 73-91.

[3] Hasibuan, M. (2015). Dasar-Dasar Perbankan. Jakarta: PT. Bumi Aksara.

[4] Nazir, M. (2013). Metode Penelitian. Bogor: Ghalia Indonesia

[5] Otoritas Jasa Keuangan. 2016. Peraturan Otoritas Jasa Keuangan Nomor 4/POJK.03/2016 Tentang Penilaian Tingkat Kesehatan Bank Umum. Jakarta: Otoritas Jasa Keuangan

[6] Otoritas Jasa Keuangan. 2017. Surat Edaran Otoritas Jasa Keuangan Nomor 13/SEOJK.03/2017 Tentang Penerapan Tata Kelola Bagi Bank Umum. Jakarta: Otroitas Jasa Keuangan

[7] Otoritas Jasa Keuangan. 2017. Surat Edaran Otoritas Jasa Keuangan Nomor 14/SEOJK.03/2017 Tentang Penilaian Tingkat Kesehatan Bank Umum. Jakarta: Otoritas Jasa Keuangan

[8] Pandia, F. (2012). Manajemen Dana dan Kesehatan Bank. Jakarta: Rineka Cipta.

[9] Pramana, K. M., \& Artini, L. S. (2016). Analisis Tingkat Kesehatan Bank (Pendekatan RGEC) Pada PT. Bank Danamon Indonesia Tbk. E Jurnal Manajemen Unud, 3849-3878.

[10] Sudirman, I. (2013). Manajemen Perbankan: Menuju Bankir Konvensional yang Profesional, Edisi Pertama. Jakarta: Kencana Prenada Media Group. 
[11] Wardiah, M. L. (2013). Dasar-Dasar Perbankan . Bandung: Pustaka Setia. 